\title{
HEPATOTOXIC AND CARDIOTOXIC EFFECTS OF TESTOSTERONE ENANTHATE ABUSE ON ADULT MALE ALBINO RATS
}

\author{
By \\ Mohamed Abd El-Aziz El-Gendy, Fouad Helmy El-Dabbah, Ashraf \\ Ibrahim Hassan and Naser Abd El-Naby Awad* \\ Departments of Forensic Medicine \& Clinical Toxicology and Pathology*, Al-Azhar \\ Faculty of Medicine, Egypt \\ E-mail: dr.gendy2210@gmail.com
}

\begin{abstract}
Background: Anabolic androgenic steroids (AASs) represent a group of synthetic derivatives of testosterone created to maximize anabolic effects and minimize the androgenic ones. Athletes use anabolic androgenic steroids (AAS) to enhance performance regardless of the health risk they may impact in some persons.

Objective: To study the histopathological and biochemical changes that could occur on liver and cardiac muscle after administration of doping dose (supraphysiological dose) of testosterone enanthate (one of AAS).

Materials and Methods: One hundred (100) male albino rats were included in the present study and divided into six groups. Group (1a); negative control group, Group (1b) positive control group treated with therapeutic dose of testosterone Enanthate $(10 \mathrm{mg} / \mathrm{Kg}$ body weight intramuscular / I.M weekly for 12 weeks), group (2) was treated with doping dose of testosterone enanthate $(60 \mathrm{mg} / \mathrm{Kg}$ body weight/ I.M for 4 weeks), group (3) was treated with treated with doping dose of testosterone enanthate $(60 \mathrm{mg} / \mathrm{Kg}$ body weight / I.M weekly for 8 weeks), group (4) treated with doping dose of testosterone enanthate $(60 \mathrm{mg} / \mathrm{Kg}$ body weight / I.M weekly for 12 weeks), group (5a) treated with doping dose of testosterone enanthate (60 $\mathrm{mg} / \mathrm{Kg}$ body weight/ I.M/ weekly for 12 weeks followed by 2 weeks of treatment discontinuation), group (5b) treated with doping dose of testosterone enanthate $(60 \mathrm{mg} / \mathrm{Kg}$ body weight/ I.M weekly for 12 weeks followed by 4 weeks of treatment discontinuation). Blood samples were collected at the start and at the end of study. Liver and cardiac enzymes were measured by usual methods. At the end of study for each group, animals were sacrificed and deeply anesthetized by diethyl ether then specimens from the heart and liver were processed for histological study using light microscope.
\end{abstract}

Results: There was no statistical significant difference in the body weight between negative and positive control group. In contrast, animals administering doping dose of testosterone enanthate for 8 and 12 weeks (group III-IV) showed a significant decrease in the body weight compared with animals of control group and group II $(\mathrm{P}<0.05)$. There was a significant decrease in the body weight of recovery group (group Va and group $\mathrm{Vb}$ ) when compared with control group ( $\mathrm{p}$ value $<0.05$ ). In the current study as regard the level of liver biomarkers (ALT-AST) had gradual significant increase all through the experimental periods. There was a significant increase in the level of creatinine kinase (CK) and CK-MB in treated groups versus control in most of experimental groups at $\mathrm{P}<0.05$ all through the experimental periods. The cardiac muscles appeared hypertrophied after doping dose of testosterone enanthate treatment. Lesions ranged from mild to severe changes were also detected depending on the dose and time of exposure. The changes were in the form of myofiber lysis, cellular infiltration, vacuolation, swelling and mitochondrial damage. Also, light microscopic results of liver of different treated groups showed histopathological changes indicating cellular damages such as necrosis, karyolysis, congestion of blood vessels and sinusoids.

Conclusion: Chronic use of testosterone enanthate in supraphysiological dose (doping dose) has a toxic effect on rat cardiac muscle and liver in the form of alteration of normal histology, hypertrophy and fibrosis 
at both histological and biochemical levels which may lead to loss of their functions. This effect was partially reversible after cessation of the treatment.

Keywords: Testosterone enanthate, supraphysiological dose of anabolic agents, Hepatotoxicity.

\section{INTRODUCTION}

Anabolic androgenic steroids (AASs) represent a group of synthetic derivatives of testosterone created to maximize anabolic effects and minimize the androgenic ones (Frati et al., 2015).

The anabolic action of AAS has been seen to exert its action on protein metabolism by the induction of protein synthesis and inhibition of protein breakdown (Houglum and Harrelson, 2011).

Very high doses of AAS have been used by athletes to improve muscle strength and physical appearance, which is the principle to increase the performance of the athletic. A variety of AASs have been used simultaneously (so-called "stacking") and in high doses that result in 10-100-fold raises in androgen concentration (Pope et al., 2017).

The most common type of AAS used for doping among bodybuilders in gyms clubs was testosterone enanthate $(31.0 \%)$ (Althobiti et al., 2018).

Different mechanism of action of AAS may exist as a result of presence of variable steroid molecules with altered action on the androgen receptors. There are various pathways of action which have been recognized. AAS is converted into dihydrotestosterone (androstanolone) by the enzyme 5-reductase. It acts on the cell nucleus of target organs, such as skin, male accessory glands and prostate (Oberlander et al., 2012).
Testosterone causes apoptosis in smooth muscle cells of blood vessels using the extrinsic apoptotic pathway that involves androgen receptor activation and reactive oxygen species generated from mitochondria (Lopes et al., 2014).

The aim of this work was to study the histopathological and biochemical changes that could occur on liver and cardiac muscle after administration of doping dose (supraphysiological dose) of testosterone enanthate (one of AAS).

\section{MATERIALS AND METHODS}

The present study was performed on one hundred (100) male albino rats of a local strain were included in the present study and obtained from animal house, Faculty of Pharmacy, Al-Azhar University. Their weight was being nearly from $100 \mathrm{~g}$ to $120 \mathrm{~g}$. The animals were housed in clear, polycarbonate cages $(40 \times$ $35 \times 30 \mathrm{~cm} 3,4$ rats per cage), with controlled air ventilation, temperature and relative humidity. Rats were placed in quarantine for two weeks prior to breeding for acclimation. The animals were fed standard rodent pellets. Food and water were made available ad-libitum throughout the whole experimental period.

Experimental Design: After 1 week of acclimation, rats were randomly divided into 6 groups:

1. Group 1 (control group): Twenty rats were subdivided into two subgroups: 
Control subgroup 1A (negative control): included ten rats given diet and water only.

Control subgroup 1B: Ten rats treated with therapeutic dose of testosterone enanthate $(10 \mathrm{mg} / \mathrm{Kg}$ body weight intramuscular /I.M weekly for 12 weeks).

2. Group (2): Twenty rats were treated with doping dose of testosterone enanthate (60 $\mathrm{mg} / \mathrm{Kg}$ body weight) I.M for 4 weeks.

3. Group (3): Twenty rats were treated with treated with doping dose of testosterone enanthate $(60 \mathrm{mg} / \mathrm{Kg}$ body weight) I.M weekly for 8 weeks.

4. Group (4): Twenty rats were treated with doping dose of testosterone enanthate $(60 \mathrm{mg} / \mathrm{Kg}$ body weight/ I.M weekly for 12 weeks).

5. Group (5a): Ten rats were treated with doping dose of testosterone enanthate (60 $\mathrm{mg} / \mathrm{Kg}$ body weight/I.M weekly for 12 weeks followed by 2 weeks of treatment discontinuation).

6. Group (5b): Ten rats were treated with doping dose of testosterone enanthate (60 $\mathrm{mg} / \mathrm{Kg}$ body weight/ I.M weekly for 12 weeks followed by 4 weeks of treatment discontinuation).

Testosterone enanthate was supplied from chemical industries development (CID) Pharmaceutical Company, Egypt in the form of oily solution ampule (250 $\mathrm{mg} / \mathrm{ml})$.

Testosterone enanthate ampoule was diluted in $5 \mathrm{ml}$ of corn oil to get concentration of $50 \mathrm{mg} / \mathrm{ml}$.
During the entire experiment, the rats were periodically weighed every two weeks. Blood samples were collected at the start and at the end of study. Liver and cardiac enzymes were measured by usual methods. At the end of study for each group, animals sacrificed and deeply anesthetized by diethyl ether, then specimens from the heart and liver were processed for histological study using light microscope.

Blood samples were collected at the start and at the end of study. Liver and cardiac enzymes were measured, total creatine kinase and creatine kinase (MB) activities were determined by a method of Young et al., (1975) usinup kits obtained from BioMed-CK-MB (EGY- CHEM), serum transaminases (ALT \& AST) activities were determined by a method reported by Doumas et al., (1971) using commercial kits from Bio-Merieux, France.

\section{Statistical analysis of data:}

The collected data were organized, tabulated and statistically analyzed using SPSS compute package version 16 (SPSS Inc. USA). For quantitive data, the mean and standard deviations were calculated, and comparisons between groups were carried out using students (t) test. For comparison between more than 2 means, the one way analysis of variance (ANOVA) test was used, and $p \leq 0.05$ was considered a significant. 


\section{RESULTS}

As regards the body weight there was no significant difference in the body weight between positive and Negative control group. Rats administer doping dose of testosterone enanthate for 4 weeks (group II) showed a similar growth with non-significant difference in the body weight gain compared to the control group. In contrast, animals administer doping dose of testosterone enanthate for 8 and 12 weeks (group III-IV) showed a significant decrease in the body weight compared with animals of control group and group II $(\mathrm{P}<0.05)$ There was a significant decrease in the body weight of recovery group (group $\mathrm{Va}$ and group $\mathrm{Vb}$ ) when compared with control group (Table 1).

Table (1): Comparison between study groups as regards the body weight

\begin{tabular}{|c|c|c|}
\hline $\begin{array}{ll}\text { Groups } & \text { Body weight }\end{array}$ & Mean \pm SD & $P$ value \\
\hline Group Ia (- ve control) & $205.6 \pm 14.9$ & 0.961 \\
\hline Group Ib (+ve control) & $203.9 \pm 11.3$ & 0.972 \\
\hline Group II & $206.6 \pm 3.7$ & 0.980 \\
\hline Group III & $196.1 \pm 10$ & 0.031 \\
\hline Group IV & $188.5 \pm 9.6$ & 0.011 \\
\hline Group V a & $192.7 \pm 15.3$ & 0.043 \\
\hline Group V b & $196.8 \pm 10.5$ & 0.039 \\
\hline
\end{tabular}

\section{Light Microscopic Results of Cardiac Muscle:}

H\&E stained sections of the cardiac muscle from left ventricle of control subgroups revealed normal structure. The muscle fibers were mostly long cylindrical striated cells with one or two, large, oval centrally located nuclei. The sarcoplasm appeared eosinophilic. They appeared in cross sections as elliptical or lobulated eosinophilic structures with nearly centrally located basophilic nuclei. The myocytes were separated by a delicate layer of connective tissue with well evidenced myocardial blood capillaries (Figure 1).

\section{Treated groups (Group II, III, IV and $\mathrm{V}$ ):}

A. Group II treated with testosterone for with for 4 weeks:
H\&E stained sections showing the cardiac myocytes hypertrophied and the cytoplasm of many cardiac myocytes was pale acidophilic displaying marked fibrinolysis with disturbed transverse striations and established many cytoplasmic and perinuclear vacuolation (Figure 2).

b. Group III treated with testosterone for with for 8 weeks:

H\&E stained sections showing widely separated cardiomyocytes and fragmented muscle fibers, these changes were accompanied with nuclear peripheralization and pyknosis (Figure 3).

c. Group IV treated with testosterone for with for 12 weeks:

H\&E stained sections showing Areas of myocytolysis, extensive degeneration, intramuscular haemorrhagic areas, numerous 


\section{HEPATOTOXIC AND CARDIOTOXIC EFFECTS OF TESTOSTERONE...}

pyknotic nuclei and others showed karyolysis and widened endomysium (Figure 4).

d. Group Va treated for 12 weeks then sacrificed two weeks after arrest of testosterone treatment:

H\& E stained section showing loss of normal architecture of cardiomyocytes, wavy muscle fibers, fibrillolysis with highly distorted

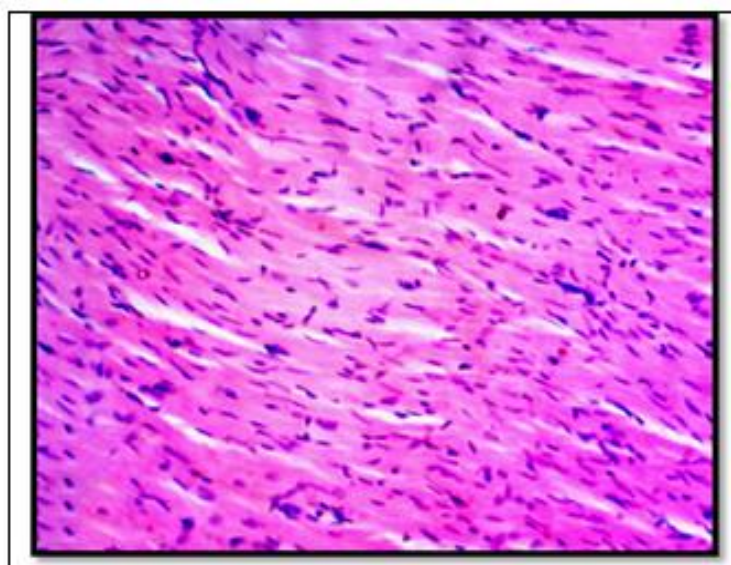

Figure (1): (Control group) long parallel and branched cardiac muscle fibers $(\mathrm{H} \& \mathrm{E} \times 400)$

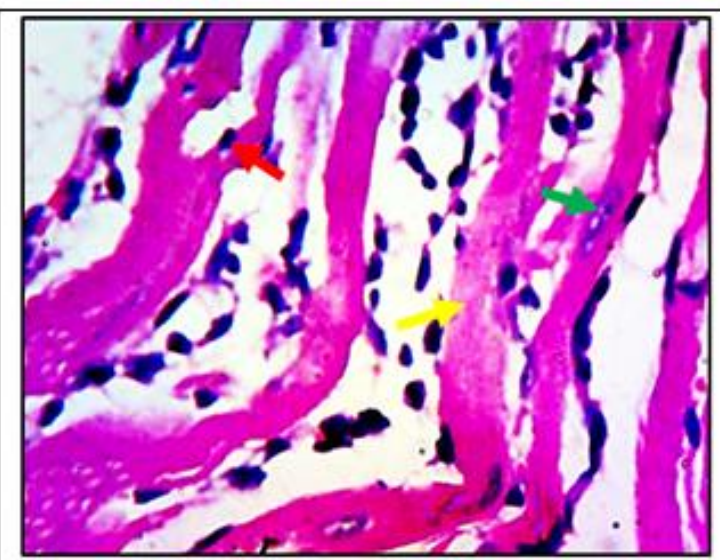

Figure (3): (Group III) H\& E stained section Cardiac muscle fibers lost their normal architecture and take a wavy shape, abundant necrotic nuclei with pylnosis (red arrow) and karyolysis (green arrow) some muscle fibers are distorted (yellow arrow). muscle fibers, obvious vacuolation and numerous blood corpuscles (Figure 5).

e. Group Vb treated for 12 weeks then sacrificed four weeks after arrest of testosterone treatment:

H\& E stained section showing fragmented muscle fibers, wavy appearance with minimal intramuscular hemorrhagic areas and pyknotic nuclei (Figure 6).

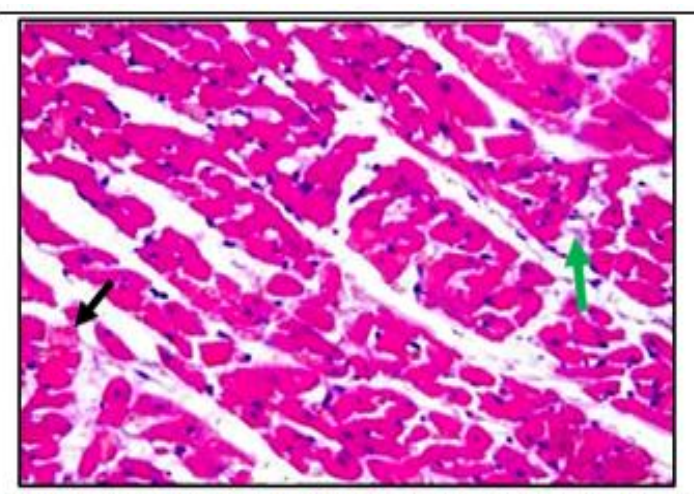

Figure (2): ( Group II) $\mathrm{H}$ and $\mathrm{E}$ stained section showing apparent hypertrophy of cardiac myocytes, pale acidophilic cytoplasm of some myocytes (black arrow) and nuclear peripheralization and cytoplasmic and perinuclear vacuolation (green arrow).

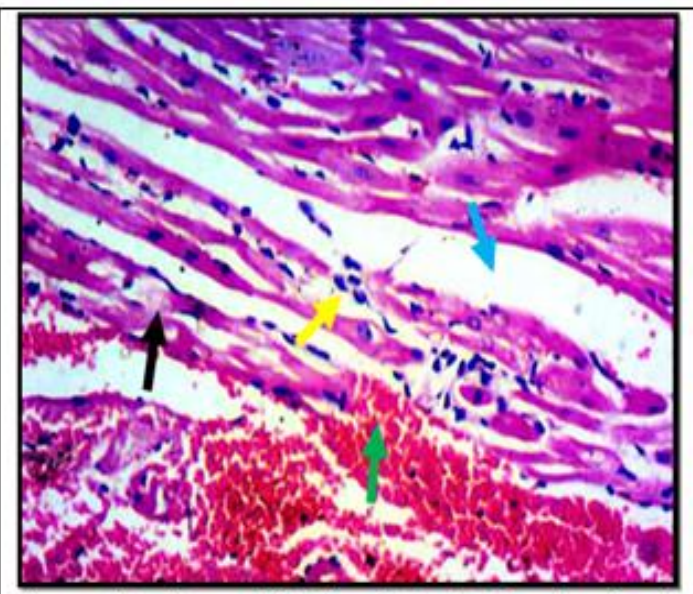

Figure (4): (Group IV) $\mathrm{H}$ and $\mathrm{E}$ stained section showing extensive degeneration (black arrow), intramuscular hemorrhagic areas (green arrow), numerous pylnotic nuclei (yellow arrow) and widened endomysium (blue arrow). 


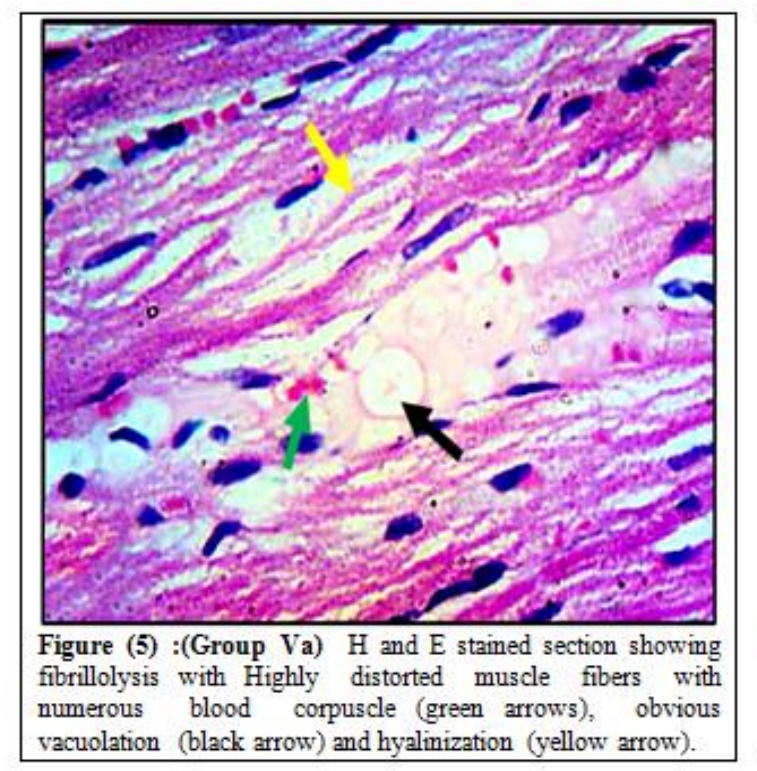

Light Microscopic Results of liver:

1. Control group (Group Ia - Ib):

H\& E stained section of liver of control group rats showed normal hepatic architecture with the central vein in the center of a classical hepatic lobule and blood sinusoids in inbetween the radiating cords of hepatocytes with normal portal tract at the periphery of classic hepatic lobule with its main components; portal venule, bile ductule and hepatic arteriole (Figure 7).

2. Treated groups (Group II, III, IV and V):

\section{a. Group II treated with testosterone} for with for 4 weeks:

H\& E stained section of liver of group II showed congestion and dilatation of the central vein and the portal venule with excessive cellular infiltration .There was also a proliferation of bile ductules (Figure 8).

b. Group III treated with testosterone for with for 8 weeks:

H\& E stained section of liver of group III showed diffuse hepatocellular vacuolar degeneration, cloudy swelling

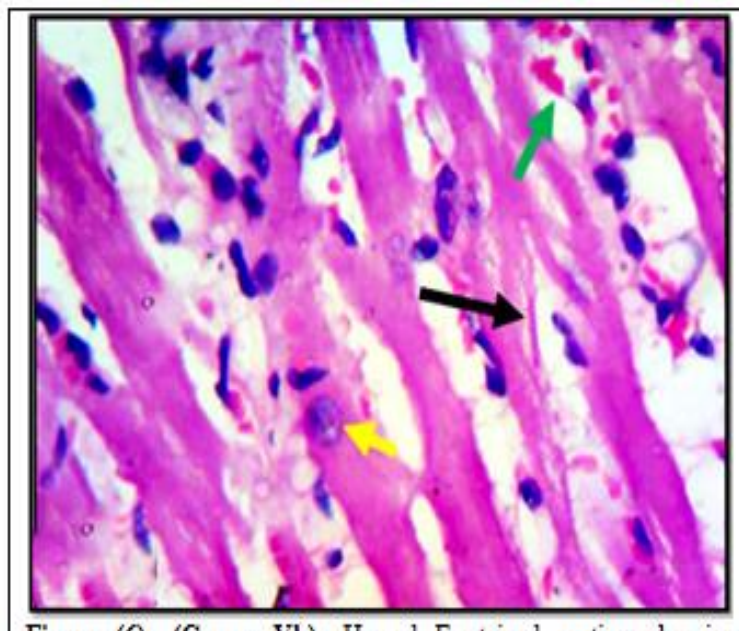

Figure (6): (Group Vb): $\mathrm{H}$ and $\mathrm{E}$ stained section showing fragmented muscle fibers (black arrows), minimal hemorrhage (green arrows) and pyknotic nuclei (yellow arrows).

hepatocytes and hyperactivation of Kupffer cells (Figure 9).

c. Group IV treated with testosterone for with for 12 weeks:

H\& E stained section of liver of group IV showing bleeding of blood sinusoids, newly formed bile duct with lymphocytic cells infiltration in portal area and coagulative necrosis of some hepatocytes and showing hydropic degeneration (Figure 10).

d. Group Va treated for 12 weeks then sacrificed 2 weeks after stop of testosterone treatment:

H\& E stained section of liver of group $\mathrm{Va}$ showed mild congestion of central vein, mild coagulative necrosis of some hepatic cells and mild newly formed bile duct (Figure 11).

e. Group Vb treated for 12 weeks then sacrificed 4 weeks after stop of testosterone treatment:

H\& E stained section of liver of group Va showed mild hydropic degeneration of some hepatic cells (blue arrow) and other hepatocytes showed normal appearance (Figure 12). 
HEPATOTOXIC AND CARDIOTOXIC EFFECTS OF TESTOSTERONE...
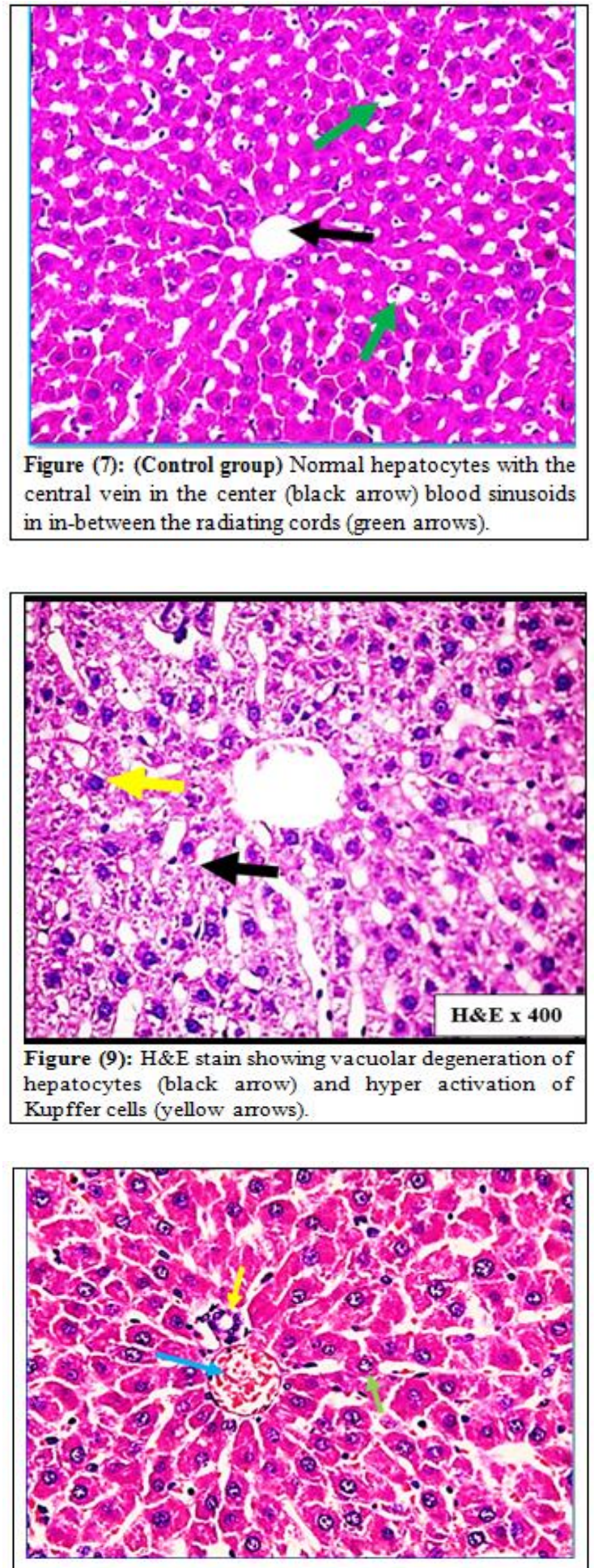

Figure (11): H\& E stained section of liver of group Va showed mild congestion of central vein (blue arrow), mild coagulative necrosis (green arrow) and mild newly formed bile duct (yellow arrow) (H\&E x 400).

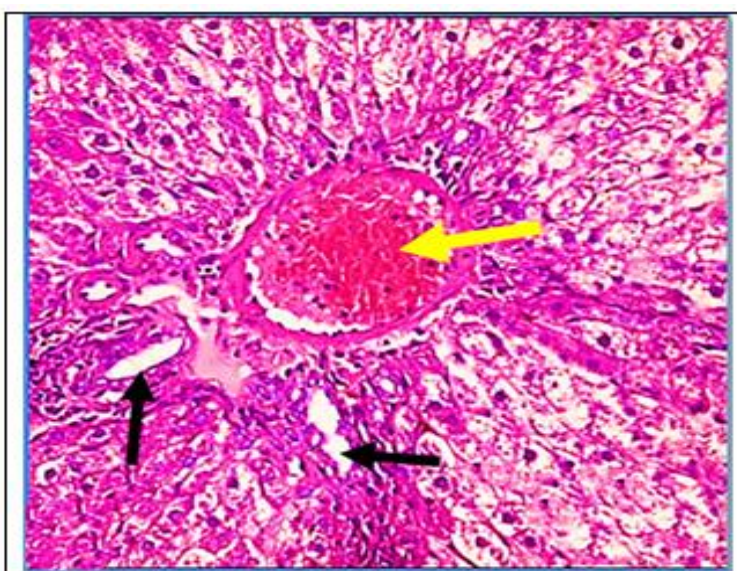

Figure (8): H\& E stained section of liver showing Proliferation and dilatation of the portal venule (yellow arrow) and bile ductules (black arrows) (H\&E x 400).

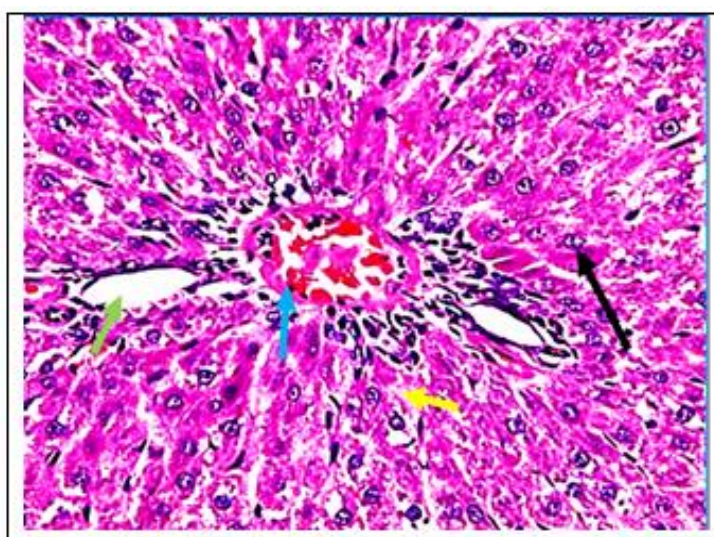

Figure (10): H\& E stained section of liver of group V showed, bleeding (blue arrow), newly formed bile duct (green arrow), coagulative necrosis (yellow arrow) and hydropic degeneration (black arrow). (H\&E x 400).

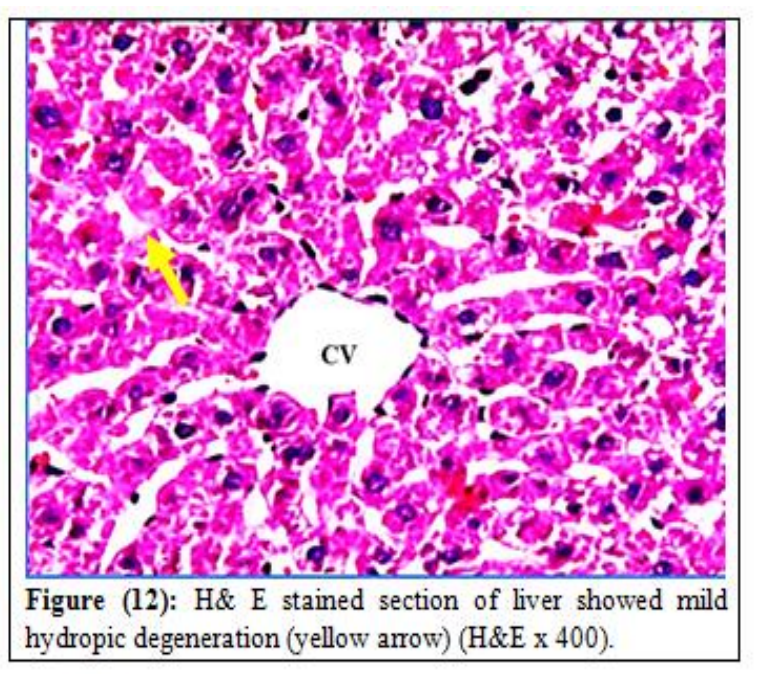




\section{Biochemical assay:}

Plasma aspartate aminotransferase (AST), (ALT) enzymes one of the liver biomarkers had gradual significant increase all through the experimental periods (Table 2).

Table (2): Comparison between study groups as regard AST and ALT levels:

\begin{tabular}{|c|c|c|c|}
\hline Liver enzymes & $\begin{array}{c}\text { AST } \\
(\mathbf{m M} / \mathbf{m l})\end{array}$ & $\begin{array}{c}\text { ALT } \\
(\mathbf{m M} / \mathbf{m l})\end{array}$ & $\boldsymbol{P}$ value \\
\hline $\begin{array}{c}\text { Groups } \\
\text { (- ve control })\end{array}$ & $35.00 \pm 26.25$ & $14.50 \pm 3.25$ & $\mathbf{0 . 9 6 1}$ \\
\hline $\begin{array}{c}\text { Group Ib } \\
\text { +ve control })\end{array}$ & $36.25 \pm 21.3$ & $15.13 \pm 5.02$ & $\mathbf{0 . 9 7 2}$ \\
\hline Group II & $60.20 \pm 16.68$ & $23.00 \pm 3.21$ & $\mathbf{0 . 9 8 0}$ \\
\hline Group III & $71.58 \pm 10.83$ & $26.02 \pm 2.24$ & $\mathbf{0 . 0 3 1}$ \\
\hline Group IV & $80.19 \pm 24.94$ & $28.40 \pm 4.88$ & $\mathbf{0 . 0 1 1}$ \\
\hline Group V a & $76.22 \pm 12.91$ & $27.17 \pm 1.78$ & $\mathbf{0 . 0 4 3}$ \\
\hline Group V b & $68.35 \pm 14.20$ & $25.05 \pm 10.1$ & $\mathbf{0 . 0 3 9}$ \\
\hline
\end{tabular}

As regard the level of total bilirubin, there was a significant increase in total bilirubin in treated groups versus control in most of experimental groups all through the experimental periods (Figure 13).

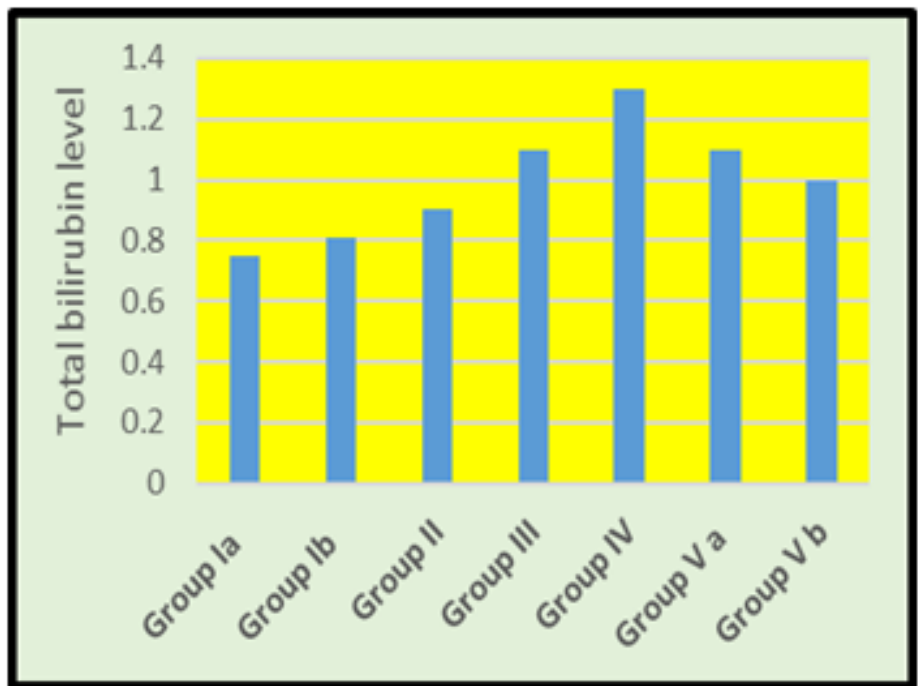

Figure (13): Study groups as regard liver function total bilinubin levels.

As regard the level of total plasma proteins and albumin there were a significant decrease in total plasma proteins and albumin in treated group especially group IV versus control groups at $\mathrm{P}<0.05$ all through the experimental periods (Table 3). 
Table (3): Comparison between study groups as regard Total proteins and albumin levels

\begin{tabular}{|c|c|c|c|}
\hline $\begin{array}{c}\text { Liver functions } \\
\text { Groups }\end{array}$ & $\begin{array}{c}\text { Total Protein } \\
\text { (gm/100 ml) } \\
\text { Mean } \pm \text { SD }\end{array}$ & $\begin{array}{c}\text { Albumin } \\
(\mathbf{g m} / \mathbf{1 0 0} \text { ml }) \\
\text { Mean } \pm \text { SD }\end{array}$ & $P$ value \\
\hline Group Ia ( - ve control ) & $5.68 \pm 0.73$ & $4.51 \pm 0.92$ & $\mathbf{0 . 1 1 7} *$ \\
\hline Group Ib ( +ve control ) & $5.62 \pm 2.4$ & $4.34 \pm 0.88$ & $\mathbf{0 . 2 1 4} *$ \\
\hline Group II & $5.58 \pm 2.19$ & $4.19 \pm 2.24$ & $\mathbf{0 . 0 4 3} *$ \\
\hline Group III & $5.14 \pm 2.96$ & $3.45 \pm 2.02$ & $\mathbf{0 . 0 3 0} * *$ \\
\hline Group IV & $4.54 \pm 4.80$ & $3.11 \pm 4.11$ & $<\mathbf{0 . 0 0 1} * * *$ \\
\hline Group V a & $4.87 \pm 12.50$ & $3.36 \pm 5.99$ & $\mathbf{0 . 0 5 0} * *$ \\
\hline Group Vb & $5.09 \pm 11.5$ & $3.61 \pm 19.33$ & $0.060^{* *}$ \\
\hline
\end{tabular}

As regard the level of creatinine kinase (CK) and CK-MB there were a significant increase in treated groups versus control in most of experimental groups at $\mathrm{P}<0.05$ all through the experimental periods with highly significance in group IV than other treated and control groups (Figure 14).

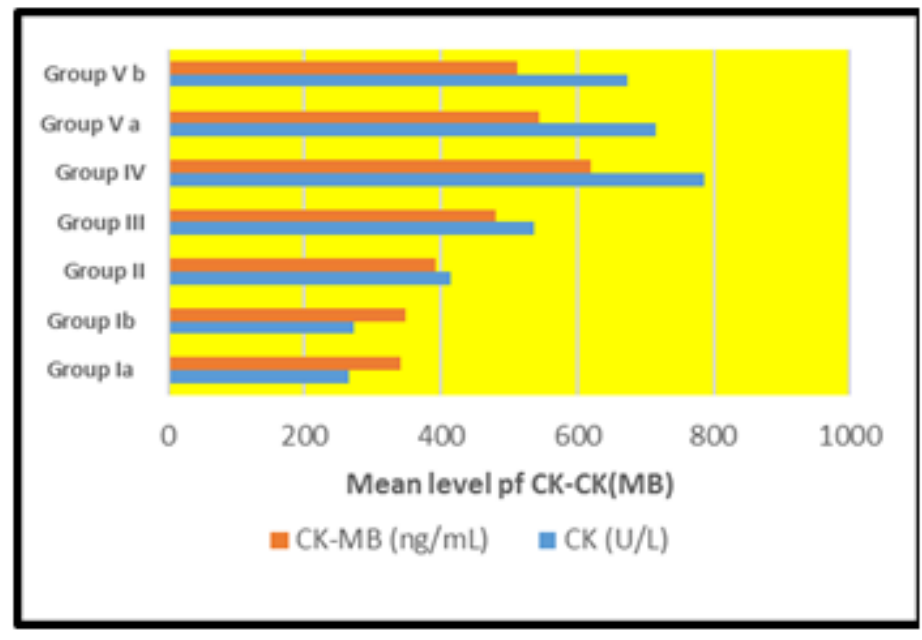

Figure (14): Study groups as regard CK and CK-MB levels.

\section{DISCUSSION}

Anabolic steroid is a synthetic variety of the male sex hormone testosterone. The anabolic-androgenic steroid (AAS) is the expression commonly used for these compounds (Lee et al., 2010).

Different mechanism of action of AAS may exist as a result of presence of variable steroid molecules with altered action on the androgen receptors. There are various pathways of action which have been recognized. AAS is converted into dihydrotestosterone (androstanolone) by the enzyme 5-reductase. It acts on the cell nucleus of target organs, such as skin, male accessory glands and prostate (Oberlander et al., 2012).

In the present study, there was no statistical significant difference in the 
body weight between negative and positive control group.

In contrast, animals administered doping dose of testosterone enanthate for 8 and 12 weeks (group III-IV) showed a significant decrease in the body weight compared with animals of control group and group II. There was a significant decrease in the body weight of recovery group (group $\mathrm{Va}$ and group $\mathrm{Vb}$ ) when compared with control group Fontana et al.2013 have reported that treatment of young male rats with an anabolic steroid leads to retardation of their growth.

There was no significant increase in heart weight between negative and positive control group (group I), and also there was no significant increase in heart weight between control group and group II. There was a highly significant increase in the heart weight observed in testosterone treated group (group III, IV and V) compared with animals of control group, this coincided with Riezzo et al. (2011) and Ahmadiasl et al. (2012) studies which reported that high dose AAS administration in mice produce significant increase in heart weight.

In contrast, Abdel Hafez (2014) reported that high-dose androgenic steroid administration resulted in a reduction in the heart weight in sedentary rats ,this difference may be due to the dose or time dependent.

In the present study, light microscopic results of cardiac muscle of different treated groups showing that the cardiac myocytes hypertrophied, marked fibrinolysis with disturbed transverse striations, fragmented muscle fibers and pyknosis.
This result was supported by Golestani et al. (2012) study who found that AAS indirectly led to mitochondrial damage, apoptosis and sarcomere disruption.

Experimental studies have shown that prolonged treatment with AAS led to dose-dependent reversible myocardial hypertrophy together with irreversibly reduced compliance of the left ventricle and decreased inotropic capacity of the myocardium (Nascimento and Medei, 2011).

In the present study, light microscopic results of liver of different treated groups showing that histopathological changes that indicated cellular damages such as necrosis, karyolysis, congestion of blood vessels and sinusoids.

Al-Aubody and Al-Diwan (2018) study showed that histopathological examination of the rats treated with AAS for period of (12 weeks) showed an increase in the incidence of liver changes include the necrosis of hepatocytes and congestion in the central vein.

Abd Hamza and Rashid (2017) study showed congestion in hepatocytes, cellular swelling, vacuolar degeneration, fatty changes and apoptosis were noticed in all AAS treated groups.

In the current study the level of liver biomarkers (ALT-AST) had gradual significant increase all through the experimental periods. This increase in activity was dose and time dependent in all treated groups.

In agreement, El-Halwagy et al. (2016) revealed gradual significant increasing in plasma aspartate aminotransferase (AST) and plasma alanine aminotransferase (ALT) enzymes through the experimental 
periods after chronic anabolic androgenic steroid (AAS) exposure.

This was also consistent with a study performed by Kahal et al. (2020) who showed an increase in plasma levels of liver enzymes (ALT and AST) with the duration of treatment accompanied by important degenerative changes in hepatic tissue after two months of treatment.

In the present study, as regard the level of total plasma proteins and albumin, there were significant decrease in total plasma proteins and albumin in treated versus control groups, this was consistent with a study performed by Lok et al. (2010) who found that long term used testosterone causing decrease in total proteins and serum albumin.

In contrast, El-Halwagy et al. (2016) showed significant increase in both total protein and albumin levels throughout the experiment depending on frequency, route of administration, and dose used.

In the present study as regard the level of creatinine kinase (CK) and CK-MB there were a significant increase in treated groups versus control in most of experimental groups at $\mathrm{P}<0.05$ all through the experimental periods with highly significance in group IV than other treated and control groups.

Karbasi et al. (2018) reported significant increase in the activity of $\mathrm{CK}$, $\mathrm{CK}-\mathrm{MB}$, and insignificant increase in AST and LDH activities in treated group with testosterone enanthate than control group.

\section{CONCLUSION}

Chronic use of testosterone enanthate in supraphysiological dose (doping dose) had a toxic effect on rat cardiac muscle and liver in the form of alteration of normal histology, hypertrophy and fibrosis at both histological and biochemical levels which may lead to loss of their functions. This effect was partially reversible after cessation of the treatment.

\section{REFERENCES}

1. Abdelhafez, H. M. (2014): Histological, histochemical and ultrastructural studies on the effect of Deca-Durabolin and whey protein isolate on cardiac muscle in adult male albino rats. International Journal, 2(10): 164-187.

2. Abd Hamza, E and Rashid, K. H. (2017): Some hepatic and renal histological and physiological effects of the artificial testosterone (Sustanon) on female rats. Pak. J. Biotechnol. Vol, 14(3): 369-372.

3. Ahmadiasl N, Najafipour H, Soufi FG and Jafari A. (2012): Effect of short- and longterm strength exercise on cardiac oxidative stress and performance in rat. J Physiol Biochem, 68(1):121-8.

4. Al-Aubody, N. M and AL-Diwan, M. A. (2018): Histopathological changes of liver, kidneys and heart of male rats caused by abusing of sustanon 250. Basrah Journal of Veterinary Research, 17(3).

5. Althobiti SD, Alqurashi NM, Alotaibi AS, Alharthi TF, and Alswat KA. (2018): Prevalence, Attitude, Knowledge, and Practice of Anabolic Androgenic Steroid (AAS) Use among Gym Participants. Materia SocioMedica, 30(1): 49.

6. Doumas, B. T., Watson, W. A. and Biggs, H. G. (1971): Albumin standards and the measurement of serum albumin with bromcresol green. Clinica chimica acta, 31(1): 87-96.

7. El-Halwagy, M. E., Abd-Alrahman, S. H., Mahmoud, R. H., Khalifa, F. K., Darwish, N. S., Attia, A. A and Mohamed, A. S. (2016): Impact of chronic androgenic steroid exposure on liver toxicity. International Journal of Clinical and Experimental Pathology, 9(2): 2652-2659. 
8. Fontana K, Campos GER, Staron RS and da Cruz-Höfling MA. (2013): Effects of Anabolic Steroids and High-Intensity Aerobic Exercise on Skeletal Muscle of Transgenic Mice. PLoS ONE; 8 (11): e80909.

9. Frati P, Busardò FP, Cipolloni L, De Dominicis $E$ and Fineschi V. (2015): Anabolic androgenic steroid (AAS) related deaths: autoptic, histopathological and toxicological findings, Curr., Neuropharmacol. 13 146-159.

10. Golestani, R., Slart, R.H., Dullaart , R.P., Glaudemans, A. W., Zeebregts, C.J. and Boersma, H.H.(2012): Adverse cardiovascular effects of anabolic steroids: pathophysiology imaging. Eur. J. Clin. Invest. 42(7):795-803.

11. Houglum, J. E. and Harrelson, G. L. (2011): Principles of pharmacology for athletic trainers (2nd ed.). SLACK Incorporated. p. 345.

12. Kahal, A., Allem, R., Zahzeh, T., Oulmane, $S$ and Tafroukhte, $Z$. (2020): Abuse of androgenic anabolic drugs with "Cycling" induces hepatic steatosis in adult male mice. Steroids, 155: 108574.

13. Karbasi, S., Zaeemi, M., Mohri, M., Rashidlamir, A and Moosavi, Z. (2018): Effects of testosterone enanthate and resistance training on myocardium in Wistar rats; clinical and anatomical pathology. Andrologia, 50(3): e12908.

14. Lee, D. M., Min, T., Choi, I., Cheon, Y. P., Chun, T., Park, C. S and Lee, K. H. (2010): Feeding effect of an anabolic steroid, nandrolone, on the male rat testis. AsianAustralasian Journal of Animal Sciences, 23 (12): 1566-1577.

15. Lok, S., Tasgin, E., Demir, $\mathbf{N}$ and Ozdemir, M. (2010): Long term used testosterone may cause heart and liver damage. Journal of Animal and Veterinary Advances, 9(18): 23432345.

16. Lopes, R. A. M., Neves, K. B., Pestana, C. R., Queiroz, A. L., Zanotto, C. Z., Chignalia, A. Z and Tostes, R. C. (2014): Testosterone induces apoptosis in vascular smooth muscle cells via extrinsic apoptotic pathway with mitochondria-generated reactive oxygen species involvement. American Journal of Physiology-Heart and Circulatory Physiology, 306(11): H1485-H1494.

17. Nascimento, HM and Medei, E. (2011): Cardiac effects of anabolic steroids: hypertrophy, ischemia and electrical remodelling as potential triggers of sudden death. Mini reviews in medicinal chemistry, 11(5): 425-429.

18. Oberlander, J. G., Porter, D. M., Penatti, C. A and Henderson, L. P. (2012): Anabolic androgenic steroid abuse: multiple mechanisms of regulation of GABAergic synapses in neuroendocrine control regions of the rodent forebrain. Journal of neuroendocrinology, 24(1): 202-214.

19. Pope, H. G., Khalsa, J. H and Bhasin, S. (2017): Body image disorders and abuse of anabolic-androgenic steroids among men. Jama, 317(1): 23-24.

20. Riezzo I, De Carlo D, Neri M, Nieddu A, Turillazzi E and Fineschi V. (2011): Heart disease induced by AAS abuse, using experimental mice/rats models and the role of physical exercise. Mini Rev Med Chem, 11(5):409-424.

21. Young, D. S., Pestaner, L. C. and Gibberman, V. A. L. (1975): Effects of drugs on clinical laboratory tests. Clinical chemistry, 21(5): $1 \mathrm{D}$. 
تاثير سميه تعاطي عقار التستوستيرون إينونثات علي القلب

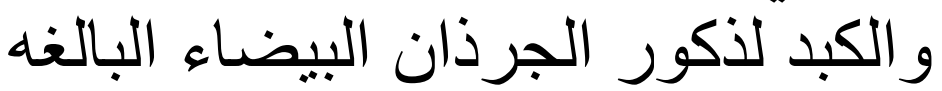

محمد عبد العزيز الجندي, فؤاد حلمي الاباح, اشرف ابراهيم حسن, ناصر عبد التبي عوض

قسم الطب الثرعي و السموم الاكلينيكيه والباتُولوجيا*, كليه طب الازهر بنين, القاهره, مصر

E-mail: $\underline{\text { dr.gendy2210@gmail.com }}$

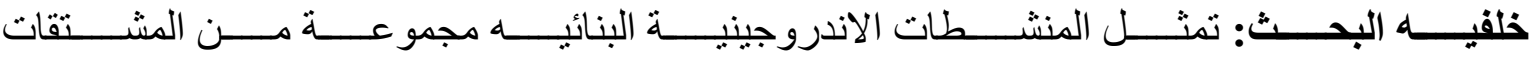

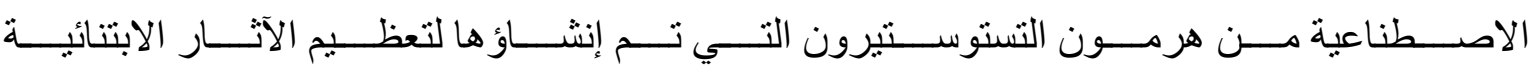

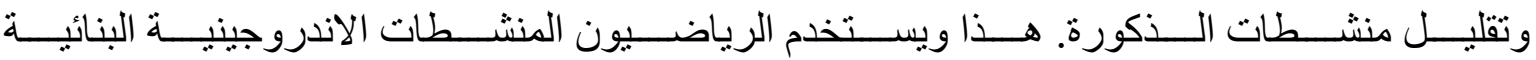

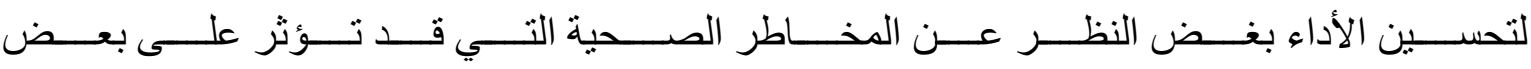
الأشخاص.

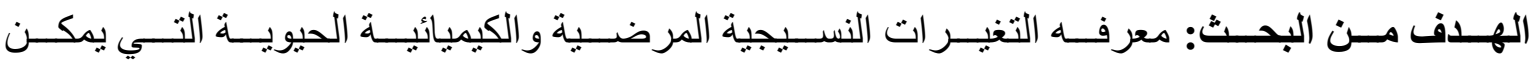

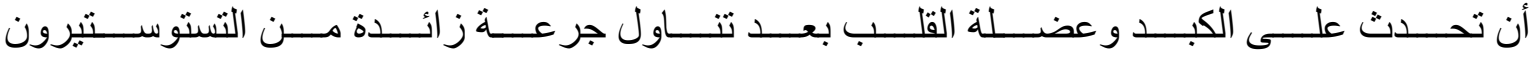
إينونثات لفتر ات مختلفه (أحد المنشطات الاندروجينية البنائيه).

المــواد وطـــق البحــث: تــم اجـر اء هــذه الدراســة علــي مائــة (100) مــن ذكــور الجــرذان

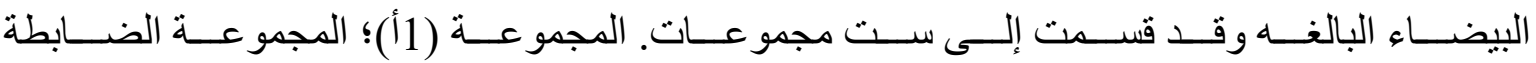

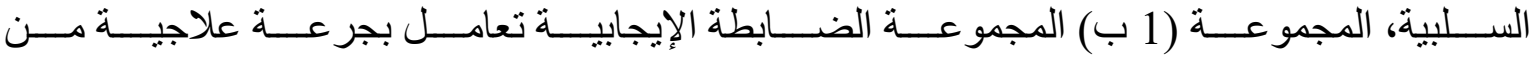

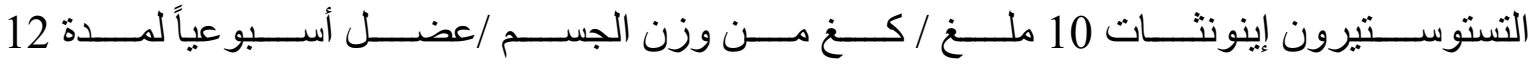

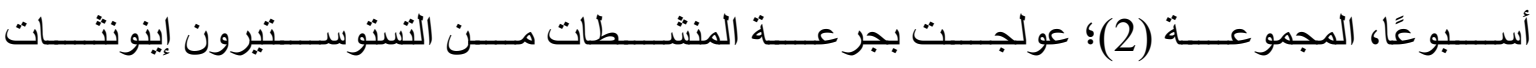

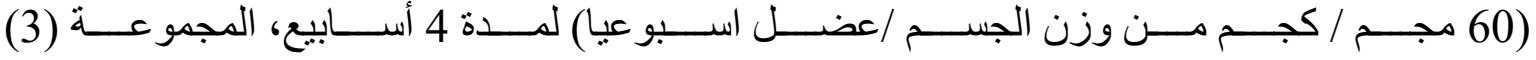

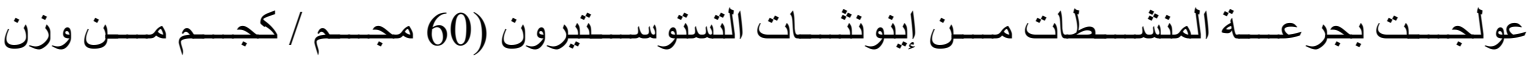

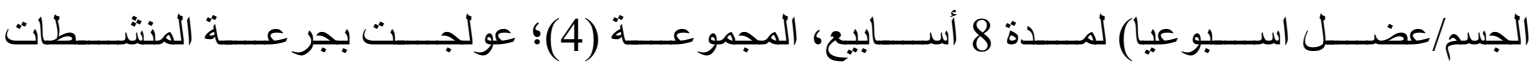

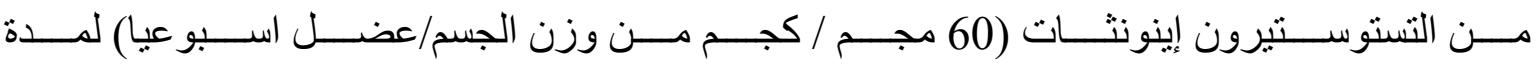

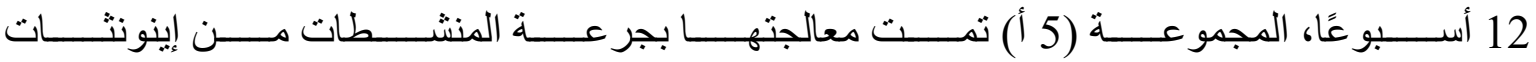

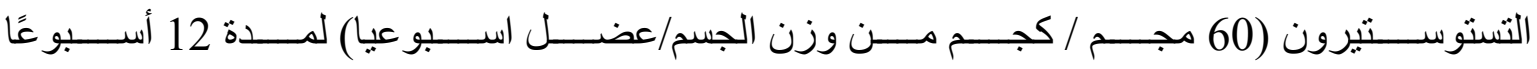

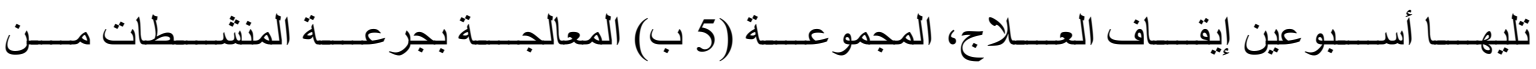

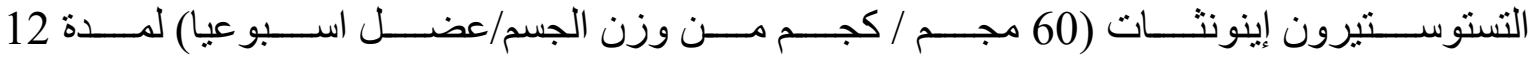




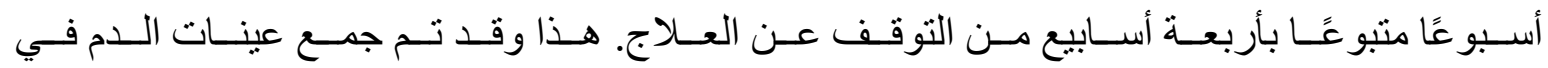

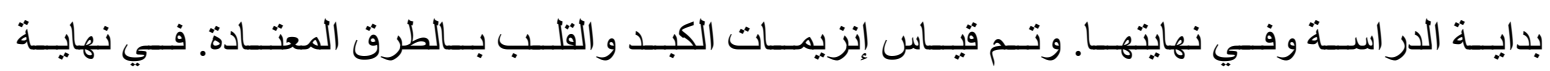

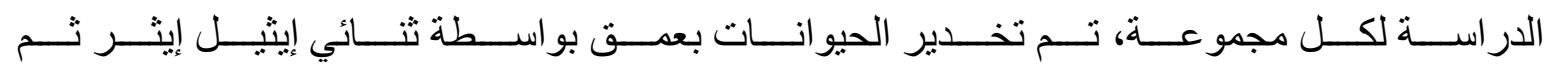
تثريحها واخذ عينات من القلب و الكبد للار اسة النسيجية باستخدام المجهر الضوئي.

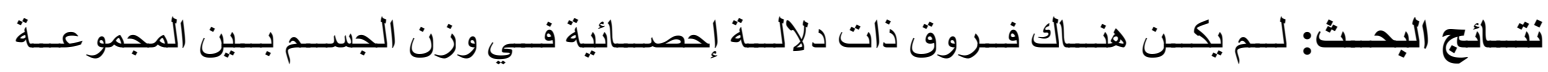

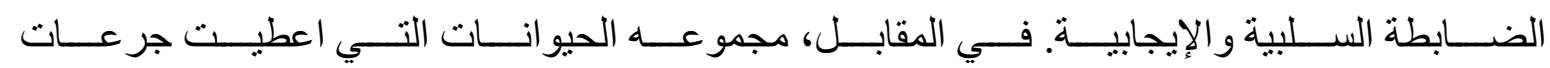

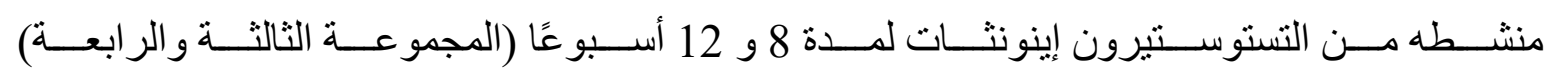

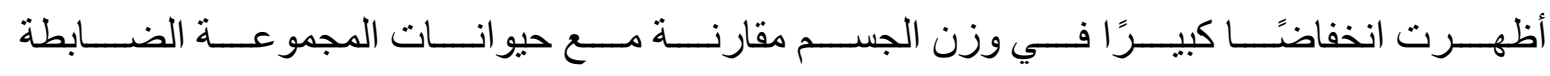

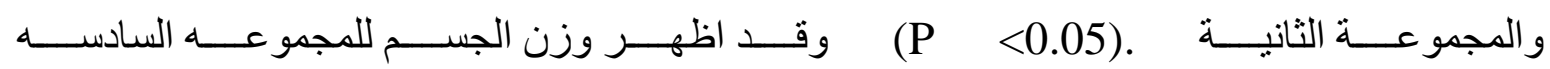

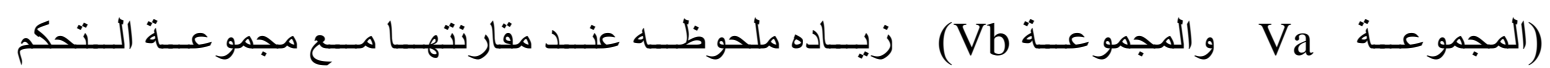

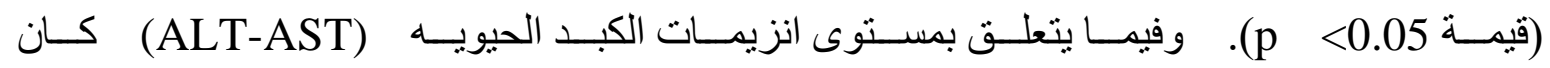

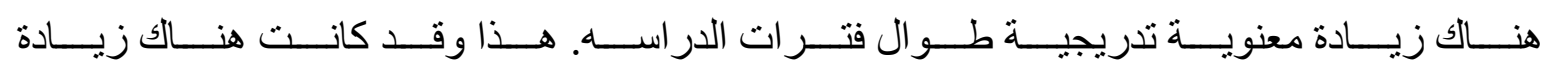

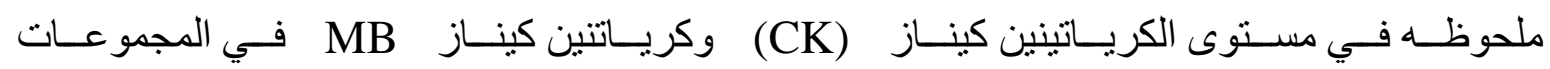

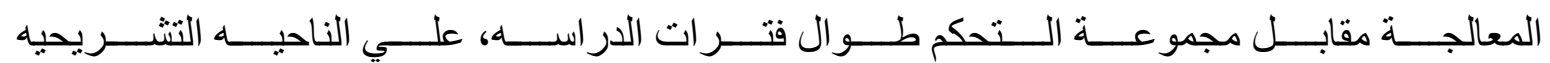

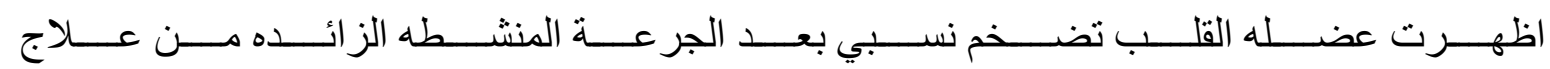

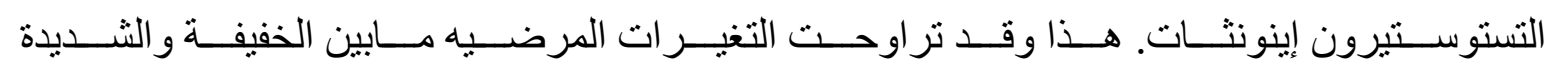

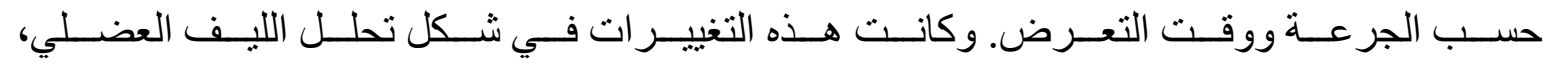

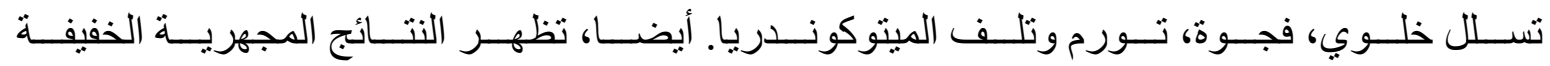

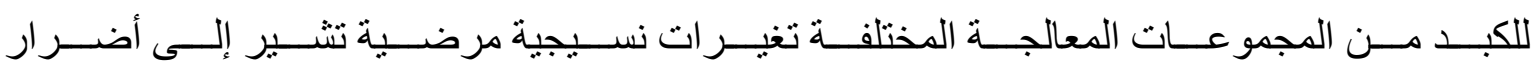
خلوية مثل النخر وانحلال النواة واحتقان الأوعية الدموية.

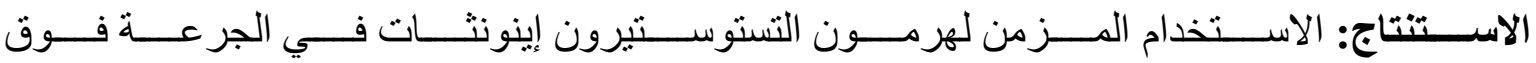

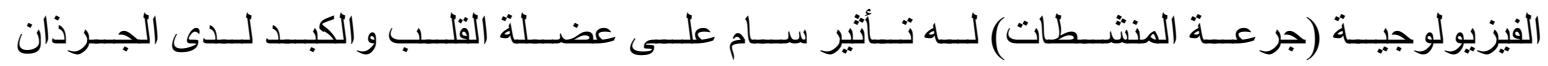

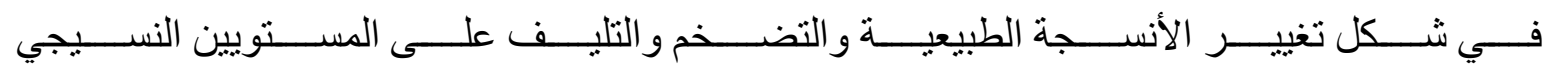

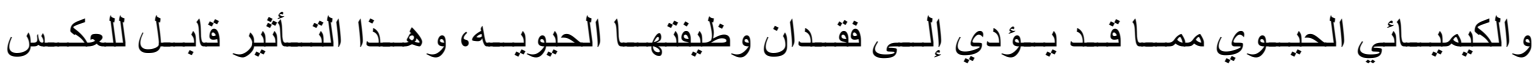
جزئيًا بعد التوقف عن العلاج. الكلمات الدالة : اينانثات التستوستيرون - سمية الكبد - عوامل البناء . 